JOURNAL OF SECURITY AND SUSTAINABILITY ISSUES

ISSN 2029-7017 print/ISSN 2029-7025 online

2021 Volume 11

http://doi.org/10.47459/jssi.2021.11.6.

\title{
CHANGING THE SOCIAL READAPTATION SYSTEM FOR SOCIAL SECURITY: FROM "SILO" SOLUTIONS TO THE INTEGRATION APPROACH - THE CASE OF POLAND
}

\author{
Slawomir Grzesiak \\ Higher School of Criminology and Penitentiary Science in Warsaw, st. Wiśniowa 50, 02-520 Warsaw, Poland \\ E-mail: slawomir.grzesiak@wskip.edu.pl
}

Received 15 November 2020; accepted 10 March 2021; published 30 March 2021

\begin{abstract}
The article presents the current model of readaptation measures, indicating possibilities for modification of the social readaptation system. It is proved the necessity to change the existing model of social support into model of social integration of excluded people for achieving their personal benefits and overall social security in society. Inclusive participation of society in social readaptation as well as the adequacy and individualization of the support offered, constitute an important component of the effective management of resources in the social readaptation system considering the people released from penitentiary institutions. To develop a holistic strategy of re-adaptation procedure it is required active and integrating participation of the society in assistive measures aimed at people leaving prisons and being at risk of social exclusion or requiring help and institutional as well as social support. Optimization of the model of social readaptation and reintegration is based on the involvement of local community, represented by the growing number of institutions and aid organizations in Poland. This integrative approach is a core feature of modern system of social re-adaptation. Hence the changes in this regard require a departure from the "silo-facade" model and focus on the "cooperative" model in order to achieve personal benefits from efficient reintegration and social security in the state.
\end{abstract}

Keywords: crime prevention, readaptation and reintegration aid, social readaptation, social security.

Reference to this paper should be made as follows: Grzesiak, S. 2021. Effective management of the resources of the social readaptation system. From "silo" solutions to the integration approach - the case of Poland, Entrepreneurship and Sustainability Issues 2021 .... (..): 91-101. http://doi.org/10.47459/jssi.2021.11.6.

JEL Classifications: I31, I38

Additional disciplines: law; political sciences; sociology; education

\section{Introduction}

Preparation of prisoners for the return to society is a complex process, which is influenced by many factors related to among others space-time (Grzesiak, Mituła-Grzesiak, 2020), personal conditions of the participants in prison and non-prison interactions (Jaworska, 2016; Felczak, 2020), like and organization of penitentiary work in this area (Szczygiel, 2002). Each of these elements is exemplified in the literature on the subject, both in the theoretical and empirical aspect (Muskała, 2016). Despite the noticeable areas of social (Supreme Audit Office, 2015; Nowak, 2020; Machel, 2008; Konopczyński, 2013; Sztuka, 2013; Stępniak, 2017) rehabilitationreadaptation-reintegration inefficiency and reformatory recommendations in this respect formulated by representatives of the world of science and practice, it seems that the Polish system of social readaptation is diverse, dispersed, uncoordinated support provided to people released from penitentiary units by individual institutions and organizations. Therefore, the question of the effectiveness of support provided to former inmates is part of the discourse about its optimal organization (Pindel, 2019; Sztuka, 2018). 
Help and support provided to people leaving penitentiary institutions should be treated as a continuation of rehabilitation and readaptation procedures initiated in penitentiary establishments. Thus, the relations between institutions of social support and society are all the more necessary. Therefore, it is necessary to opt for such a "model of prophylaxis that would fulfil the functions of anticipatory prophylaxis and at the same time a restraining one, concentrated on the individual in a micro-social scale, and on social structures and appropriately cooperating institutions in a macrosocial scale" (Pytka, 2005). In this approach, it is important to perceive the excluded person as an entity embedded in a wider social context, interacting with its environment, and not in its margins. The above approach assumes that the successful course of the process of social re-adaptation requires not only working with an individual leaving prison, equipping that person with necessary knowledge and skills, but also preparing the environment (especially the family) to give support and play an active role in this process (Stasiorowski, 2019). Been involved to the human development via the participation in social interactions, which are important feature of sustainable dialogue and cohesion (Bilan et al., 2019; Mishchuk et al., 2019; Świerczyńska $\&$ Kliber, 2018), such people obtain their possibilities for real rehabilitation. Such willingness of the society to accept people leaving prisons and providing them with support in the Polish social resocialization thought is defined as the readaptation capacity of the society (Machel, 2006), with H. Machel pointing out that, in addition to this assistance, people released from penitentiary institutions require the efforts of many institutions and services in this area, as well as the willingness to changes in life so far by socially maladjusted people.

\section{The "silo" model of the social readaptation system}

Both the state and its citizens should strive for the effectiveness of the resocialization of criminals (Deka, 2017), as the entire society benefits therefrom. Therefore, many institutions and services undertake activities aimed at resocialization and readaptation of convicted people, bringing them closer to the society or restoring them into the society. This often requires cooperation between various institutions and is associated with the constant necessity to improve the forms of this cooperation. The need to change the mentality of a significant part of the society with regard to the manner of treating ex-prisoners (Szczepaniak, 2014) as well as the activation and education of local communities to which people released from penitentiary establishments return constitute important issues. The current system of social readaptation in Poland is presented in the figure below.

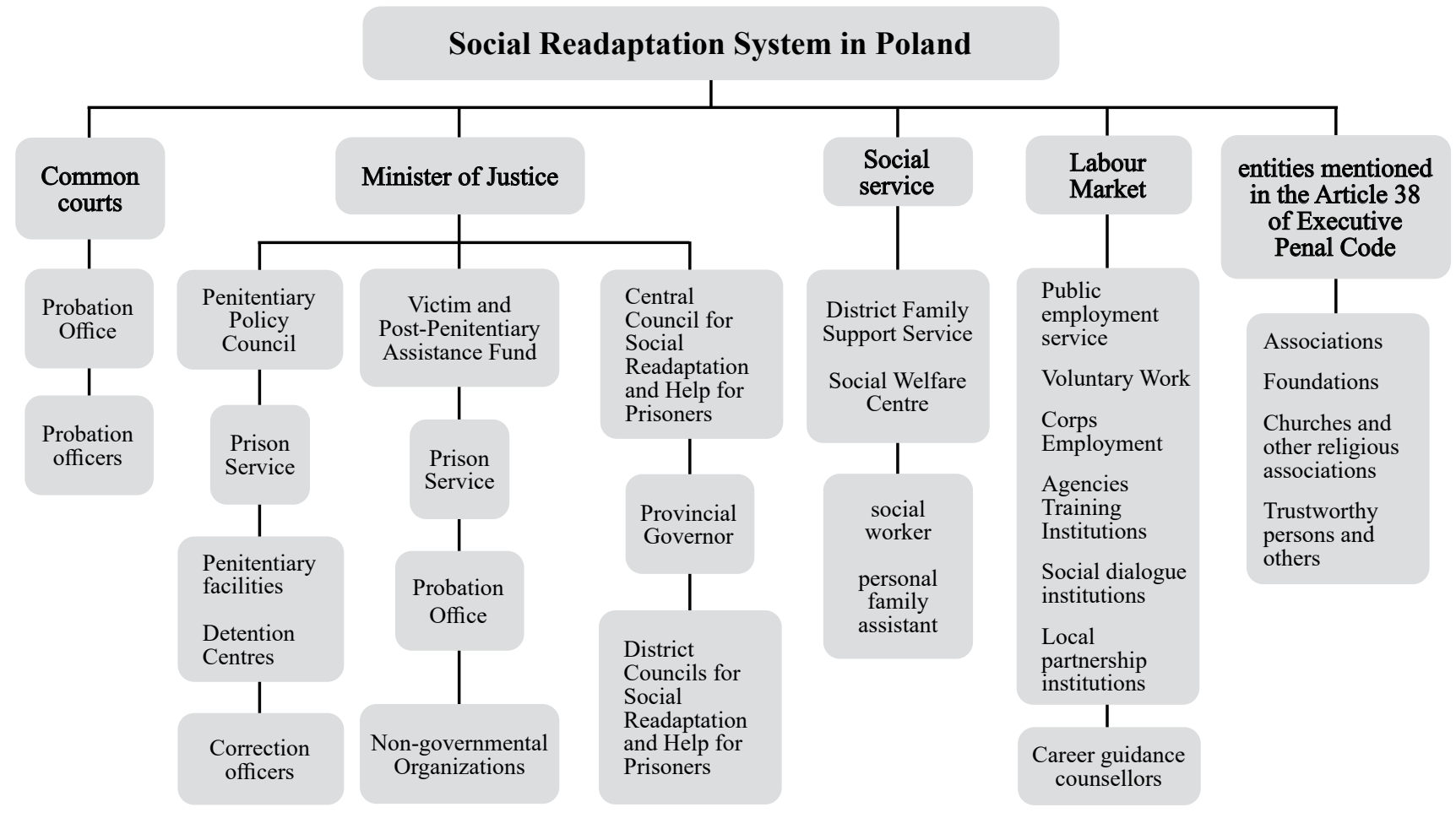

Fig. 1. The system of social re-adaptation in Poland 
Based on the analysis of this pattern, it is noticeable that the prevention and prophylaxis of relapsing crime is the task of many state institutions which create the penal and social policy in the local and national dimension (Szymanowski, 2005, 2010; Morel et. al. 2015; Gawrycki, et. al. 2012; Piątek, et. al. 2016). It would seem that institutional and non-institutional resources are so plentiful and diverse that within their scope they penetrate the areas of social support being of significance for people subject to decarceration. However, the reality is that these assumptions do not always work wellin practice. Many of the forms of assistance are duplicated, ineffective, territorially limited and assume insufficiently low participation of the society, especially local communities, into which the person released from prison returns (Supreme Audit Office, 2018).

Appropriate preparation of the people serving an imprisonment sentence until the moment of release and subsequent surrounding them with various forms of support (material and non-material), as well as monitoring the progress of reintegration until the achievement of civic self-reliance (Giddens, 2003; Institute of Civil Affairs, 2021) is important from the point of view of managing the social support network. The functional aspect of the social readaptation system presented above is archaic, which manifests itself in planning, organizing, deciding, motivating and controlling the measures undertaken in relation to people leaving penitentiary units, as well as in the fact that some services refrain from cooperation with other services in the field of assistance provision (Bitkowska, 2019). Assistive and support measures are not fully adequately employed to achieve the goal of the optimal social reintegration of an ex-criminal (Sztuka, 2018).

Moreover, it should be noted that the prevention of relapsing crime belongs in the qualitative model of cooperation between individual institutions, and not in the quantitative approach to incorporating people being at risk of exclusion into the society, which is mainly characterized by the material and living aspect. In terms of the benefits provided and the measures and methods used by various support institutions and organizations, the evaluation of their activities is positive, which does not translate into the evaluation of the readaptation effects achieved (Jaworska, 2016; Fidelus, 2012; Stasiorowski, 2016). Therefore, departure from the "silo" (Stasiorowski, 2017) or "tunnel" (Nowak, 2016) model of social action towards a systemic approach to the dependence of man and the environment in social inclusion and exclusion seems to be an urgent necessity.

The above findings are also referenced in the reports of the Supreme Audit Office (2018) concerning, among others, the subject of social readaptation of convicts, in which it was indicated that the assistance measures employed for the people leaving penitentiary units are fragmentary and do not take into account the need to simultaneously cover many spheres of the functioning of people deprived of liberty, i.e. the spheres of family, professional life or health, with coordinated re-adaptation measures. The reasons underlying this state are, among others (Supreme Audit Office, 2015):

a) the lack of a uniform normative act which comprehensively and precisely defines the system of cooperation and support for services for the benefit of socially excluded people. Implementation of numerous tasks by various independent of each other entities, resulting from separate regulations, leads to quantitative and qualitative differentiation of the provided assistance services depending on the region of the country. Moreover, it consists essentially in the takeover of service provision by successive institutions, and does not constitute individual, customised support in readaptation and reintegration;

b) quantitative predominance of emergency aid related mainly to meeting the basic needs of people leaving penitentiary institutions over qualitative sensitivity and flexibility in shaping the readaptation and reintegration resources of people returning to the society;

c) standardization of activities, without taking into account the special needs and categories of the beneficiaries of such activities and their families.

Additionally, the reports of the Supreme Audit Office point to the conclusion that multifaceted social readaptation requires the development of rules for cooperation and coordination of activities of all entities participating in this process - the offer of which is to be available to every person in need. Passing a readaptation act would be such a solution unclogging the system in terms of the competences and management, which would certainly solve many issues related to providing social support to people in need,at different levels of administration and areas of its provision (Second Chance Act of 2007; Nowak, 2015). An efficient system of social readaptation 
is one of the key conditions for curbing the phenomenon of criminal recidivism (Zygmunt, 2008; Szczepanik 2015; Kosonoga-Zygmunt, 2016; Muskała, 2016). Assessments and opinions are formulated from the perspective of the widely understood effectiveness of the social readaptation system and they concern the needs and possibilities of taking specific measures aimed at optimizing the existing readaptation and reintegration practice. Hence, the general scope of its measures relating to the resources at its disposal, should ensure conditions for an effective process of social reintegration, the deliverable of which is social inclusion.

The growing tendency for relapsing crime that has been observed for years implies the need to evolve the existing methods of preventing criminal recidivism in, among others, the area of readaptation and reintegration of people released from penitentiary facilities (Central Management Board of the Prison Service, 2021). That requires a change in the existing aid strategy, one which strengthens the competences of individual institutions instead of creating a real, systemic organisation of social support for institutions cooperating with local, regional or community societies (Nowak, 2016).

\section{Integrative strategy of the social readaptation system}

The literature on the subject points to the conclusion that the analysis of the Polish system of social readaptation focuses on the search for its optimal model and effective management of the current readaptation resources. Considering the fact that the issues raised are focused on activities preventing the repeated violation of legal norms; by means of these activities there is an attempt to make the psychosocial change of people leaving penitentiary institutions real. In terms of criticism concerning the Polish system of social readaptation, it is necessary to consider an organisation of the social support system differing from the current one which in fact is more of a facade than a system.

For years, many Polish researchers have been suggesting different model solutions for social readaptation. The conceptual recommendations for the reorganisation of the social readaptation system refer both to the tradition of Polish pedagogical thought by H. Radlińska, A. Kamiński, T. Pilch or S. Kawula (Nowak, 2012), as well as to the current foreign solutions (from the USA, Canada, Great Britain, Australia) which are part of the trend for desistance from crime and desistance from social readaptation, the concept of managing financial resources allocated to the justice system (justice reinvestment), the concept of organising and activating local communities (community development), the strategy of interaction based on evidence (evidence-based practice, the Good Life Model or the concept of managerial crime management (new penology) (Barczykowska, Muskała, 2017; Pospiszyl, 2020). And thus A. Bałandynowicz (2010) is the author of the multi-thread concept of social rehabilitation with the participation of the society; W. Ambrozik (2016) developed the idea of the socialisation of prevention and rehabilitation system; the works of B. M. Nowak $(2014 ; 2016)$ refer to the network and system concept of social (re)integration; A. Kieszkowska $(2012 ; 2019)$ points to the inclusive and catalytic concept of the model of social reintegration, while A. H. Fidelus $(2017 ; 2019)$ suggests social and spatial solutions.

A common element of the above-mentioned approaches to social readaptation is the participation of local communities; as a matter of fact, the main readaptation and reintegration plans relate to work in local communities, where crime is the greatest nuisance. Hence there appear proposals to form and introduce different institutions and organisations to these communities as an element supporting social inclusion. Examples of such solutions are district readaptation support offices (Nowak, 2016), family therapy homes (Bałandynowicz, 2006), transition homes (Grzesiak, 2019) or third-sector organisations carrying out tasks commissioned under the social readaptation system (Ambrozik, 2016).

Having regard to the premises of individual readaptation concepts, it is possible to indicate other general features of the integration strategy for the system of the social readaptation of people released from penitentiary facilities and endangered by social exclusion. Therefore, it is necessary to develop an integrative, systemically complementary strategy of social readaptation, interdependent and consistent with its components, in accordance with the current state of knowledge and research in this field, taking into account the voices indicating usefulness or uselessness of the existing assumptions. These are only holistic and systemic solutions that will 
allow for the establishment of an effective aid procedure for people who are at risk of social exclusion and crime. That requires establishing an interdisciplinary team of experts: scientists, practitioners, representatives of all aid institutions participating in the practice aimed at social readaptation, who, based on research and knowledge of the possibilities and limitations of their actions, can effectively contribute to developing an optimal model of social support.

When working on the modification of the current system of social readaptation, it is first of all necessary to take into account the results of scientific research and critical voices regarding which elements of the impact measures do not find application and why. An effective strategy of systemic social support must be based on scientific evidence, catallactics of knowledge and practice, as well as evidence-based practice. Only knowledge and practice, complemented by solid empirical research on the readaptation and reintegration activities and their effects, allows for using time, energy and resources available to aid institutions appropriately. Empirical research is backed by a particular methodology which allows for determining to what extent and under what conditions the measures taken bring the most benefits in the individual, institutional or social area. The knowledge which is "as accurate as possible, as certain as possible, as general as possible, as simple as possible with the maximum content of information" (Pilch, 2001) is the foundation for planning and implementing effective assistance interventions; it also allows the verification of perceptive opinions on the reintegration of convicts into society, as well as carrying out activities in the area of social destigmatization (Nowak, 2020). Of particular value for the implementers of change-inducing measures, in addition to being demanding, are studies in the field of criminology and penitentiary science, conducted in a longitudinal perspective, which analyse the period of criminal or problem anamnesis and catamnesis. The methodical regime which is based on the time continuum allows for determining the trajectory of highs and lows in the biography of a person experiencing difficult life situation, thus providing information about individual criminogenic conditions, as well as about readaptation resources which should be activated in a specific case.

The complexity of the proposed systemic readaptation solutions is also necessary. Management of individual and social change should include all activities of the readaptation and reintegration methodology, mutually complementing activities which are backed by knowledge and empiricism as well as methodological practice; and this management should not be restricted only to the implementation of individual activities in separation from the structures of civic society, particularly local communities (Regulation of the Prime Minister, 2016). In this area, the prevention of criminal recidivism should be treated in a sensu largo, as the overall impact of institutions, organisations and society on the person leaving prison, while maintaining the integrity of goals. One cannot narrow down readaptation measures only to the implementation of a certain program or a specific intervening party's conduct, but it must be a holistic strategy of the readaptation procedure. Only the multitude of activities, their repeatability, stability and orientation towards the assumed goal or goals may be an indicator of tasks and functions as regards individual, group, local and institutional aid and assistance.

Another inherent quality of effective aid and assistance interventions is their interdisciplinarity and methodological diversity. Interdisciplinarity is the key to understanding risk and protective factors (Fidelus, 2012). It is the foundation of the development and assessment of effective prevention strategies. A broad view at the stage of implementing support measures also allows flexible selection of the methods of operation in order to remove or optimally reduce the influence of significant risk factors, or to reduce/compensate them by strengthening protective factors. Interdisciplinarity is a holistic approach to the recipient of specific aid measures; it is also the approach to dimensions of support in the case of social exclusion, which may be more or less biographically episodic.

The effectiveness of the systemic readaptation strategy also requires holistic interactions. Obviously, there are some individuals who do not need social rehabilitation or re-adaptation interactions and for whom there is no need to undertake such interactions, but the withdrawal from them must result from an in-depth rehabilitation-readaptation-reintegration diagnosis. The whole range of institutional and non-institutional procedure applied to a person released from a penitentiary unit, should address all spheres of human development, i.e.: physical (biological), psychological, socio-cultural and spiritual. However, most 
often rehabilitation and re-adaptation measures relate to the socio-cultural sphere and therapeutic activities to the psycho-physical sphere. On the other hand, the spiritual sphere, with which the system of human norms and values is related, often remains a neglected re-adaptation area. In turn, medicine proves that the process of human recovery requires not only strictly medical procedures related to the patient's physical health, as their mental condition is of equal importance. Hence, the need to support the pharmacological treatment process with therapeutic, psychological activities, the presence of relatives, or the involvement of the representatives of religious communities. Empirical research indicates the need to treat a person not only in the area of their physicality or psyche, but also spirituality, which may have a significant impact on psychosomatic and behavioural disorders (Galanter et. al. 2009; Mastalski, 2006).

The systemic strategy of re-adaptation also requires people who are competent as well as committed to this process, responsible for supporting people at risk of social exclusion or crime, hence it is very important that the people who help are professionals, have the adequate knowledge, competences and praxeological skills which are necessary for their practical application. Re-adaptation and re-integration measures applied to people leaving penitentiary institutions as well as those who find themselves in a difficult life situation on the margins of social life, due to their so-called "volatile nature", should be a constant search for effective post-penitentiary and pro-inclusion solutions. At the same time, the wealth of literature on the subject and the multiplicity of concepts regarding assistive measures, their effectiveness and conditions for providing support instead of helping, may paradoxically hinder its provision, causing a certain confusion in the practitioner of re-adaptation and re-integration work, which in turn may affect the quality of measures undertaken by them in the institutional and social space. Having knowledge in the field of social support allows for eliminating errors in the practice of re-adaptation and re-integration and directs one towards effective pro-inclusion interventions. In the case of the implementers of tasks in the field of social support these lines of search should be included in their professional self-improvement process, in which they should not be alone, especially at the stage of implementing projects such as freedom programs (Iwanowska, 2013), programs supporting in a material and non-material way (Ministry of Justice, 2021; Lewicka-Zelent, Stasiorowski, 2020), programs of integration with the environment and with the participation of this local environment (Association PEOPLE FOR PEOPLE; POMOST Foundation; PATRONAT Penitentiary Association). Schematic, routine and superficial measures do not bring the expected results and may even harm and discourage any activity on the part of the beneficiaries of aid and support interactions (Supreme Audit Office, 2018; Marzec-Holka et. al. 2014). That is why it is very important to become thoroughly acquainted with the achievements of science in this dimension to date, to comprehensively think over the entire project and plan activities as a whole, involving not only the implementer/s and the beneficiary/ies of impacts, but the entire institution/organisation. If a program or a project does not have solid theoretical, teleological and methodological foundations, its implementation will not change anything except the obvious increase in documentation. The implementation of all forms of assistance and support should take into account the basic principles of effective corrective interventions (Stańdo-Kawecka, 2010). It should also be a challenge for the entire administration in the process of change management understood as a triad: individual change in the convict, institutional change in thinking about measures taken towards marginalized people and social change in participation of external entities in conducting readaptation and pro-inclusion measures.

An indispensable element of an effective aid strategy is also the cooperation between institutions and persons involved in the readaptation activities being implemented, as managing change in the prevention of criminal recidivism is not the action of one person (educator, psychologist, probation officer, social worker) or even one institution (penitentiary unit, probation court service, social welfare centres), which is also noticed in the literature on the subject (Bulenda, Musidłowski, 2003), where attempts are made to indicate systemic solutions which are now rather fragmented than forming a coherent system of social support. The cooperation of various institutional and non-institutional entities on the basis of reciprocity may be fruitful in re-adaptation and reintegration measures, in which persons representing these entities can support with experience and knowledge, often highly specialised due to the narrow scope of their statutory tasks in a given field. These types of activities also have additional advantages because the beneficiaries of the interventions are more willing to participate in such meetings, e.g., due to the fact that they do not equate assistive persons with an oppressive apparatus. This 
implies the necessity to reorganise the principles of cooperation between institutions involved in social support provision. Such measure is related to the solidarity in strengthening public safety in terms of its public and personal perception by citizens. Therefore, optimising the cooperation of various institutions and organisations is a necessity resulting from the principles of social solidarity. There are a number of different institutions which, as part of the tasks entrusted to them by applicable laws or their statutory activity or individual needs to bring assistance, can become part of the systemic re-adaptation strategy, e.g. the Prison Service, the Probation Court Service, Social Welfare Centres, the Central Council for Social Re-adaptation and Assistance for Inmates, District Labour Offices, Local Government Institutions, Hostels and Shelters for the Homeless (self-governmental and run by third sector organisations, for instance: Towarzystwo Pomocy im. Św. Brata Alberta [St. Brother Albert Assistance Association]), Churches and religious associations, non-public entities - the third sector, which in the course of their statutory activities help people leaving penitentiary units, but also victims or deal with broadly understood civic education (e.g. Wrocławskie Towarzystwo Opieki nad Więźniami, Stowarzyszenie Penitencjarne [Wrocław Society for the Care of Prisoners, Penitentiary Association] Patronage, Polskie Towarzystwo Penitencjarne, Stowarzyszenie [Polish Penitentiary Society, Association] Klinika art. 44 article KKW [Clinic of Art. 44 of the Executive Penal Code], Stowarzyszenie Pomocy [Assistance Association] Ludzie ludziom [People for people]; cultural and artistic institutions: theatres, community centres, artistic groups; care, education and rehabilitation centres for children and adolescents (Orphanages, Youth Educational Centre, Youth Centre for Social Adaptation)as well as caring for adults (Nursing Home, community Nursing Homes); universities (research and teaching staff, doctoral students, students of science clubs); volunteers.

Conducting social rehabilitation and re-adaptation interactions in institutional conditions requires the consolidation and continuation of these activities in a free environment if change-creating interventions are to be effective (Stańdo-Kawecka, 2010; Sztuka, 2007). Therefore, cooperation with the indicated institutions seems to be a natural continuation of the measures taken at the stage of serving imprisonment sentences. In line with previous rehabilitation and therapeutic interventions, post-change management is the necessary next stage of socio-cultural inclusion (Grzesiak, 2017).

It should be remembered that the process of change management, which social rehabilitation and re-adaptation interactions should constitute, does not mean that the risk of problem occurrence is reduced. Even if intervention measures seem logical, based on the theory or simply common sense, there is no guarantee that they will bring benefits or that the desired outcome will be attained, which in the case of working with another person may always be merely anticipated. However, that does not change the fact that it is necessary to conduct this type of interactions, which implement social expectations in relation to social rehabilitation and re-adaptation services and also social participation in this area. Hence, the attention to the indicators of the effectiveness of activities:

- at the stage of conceptualisation of interactions - the substantive quality of the strategy of measures,

- through the implementation of specific solutions - the quality of implementation and evaluation of measures,

- but also, a soft category, which is the atmosphere created by the supporting intervener, in which this type of procedure takes place - the quality of the supporting institution (Kojder, 2001) in the area of its operation on the continuum of the learning institution/organisation versus the mindless institution/organisation (Crawley, Sparks, 2005),

- it seems to be a necessary condition for the discourse on the system of social re-adaptation in Poland.

The postulated elements and features of the systemic integration strategy of social re-adaptation derive from various concepts recommending the need to depart from the current "silo" model of social support, and at the same time point to the need of merging and tightening interdisciplinary cooperation in reaching the meta-goal of positive social inclusion. At the same time, they assume an individualized methodological approach which recognizes and takes into consideration the variety in the ways of working with individuals who need help and support, and with diverse groups of people. In its implementation, it requires effort, both from the beneficiaries and institutions and organizations providing such assistance, and also sets directions to be followed when planning, implementing activities leading to a positive institutional and social change, and consequently preventing criminal recidivism. 


\section{Conclusions}

Recognizing the possibilities and limitations of the current perspective of the social readaptation of people leaving penitentiary institutions is an element of diagnosis and assessment of current solutions. However, one should not be satisfied with describing and assessing the current state, but rather indicate and look for solutions with which to effectively manage the resources of the social readaptation system. The literature on the subject indicates theoretical and empirical premises for the evolution of existing solutions, and pro-inclusive social education ushers into the public discourse the issues of people requiring social support, which constitute an inseparable subject of social life, persisting around us, and their institutional change is ineffective and uneconomical. The community corrections trend and the idea of a model of social readaptation based on the potential local environment are gaining increasing popularity, as evidenced by the growing number of institutions and aid organizations. The cooperation of services and society seems to be a constitutive feature of the modern system of social re-adaptation, hence the changes in this regard, require a departure from the "silo-facade" model and focus on the "cooperative" model.

Crime in Poland and returning to crime are among the basic determinants implicating a sense of social and personal security of citizens (Grzesiak, 2019a). Therefore, the reorientation of the way of thinking and managing social support as well as the resignation from penal populism seem to be indispensable for the effective management of re-adaptation resources.

\section{References}

Ambrozik, W. (2016). Social rehabilitation pedagogy. Towards the socialization of the system of interventions. Cracow: Impulse Publishing House.

Bałandynowicz, A. (2006). Family therapeutic homes as a resocialization in an open environment. Warsaw: Polish Society of Mental Hygiene.

Bałandynowicz, A. (2010). Multi-level theory of social resocialization. Polish Journal of Social Rehabilitation, 1, $121-156$.

Bilan, S., Mishchuk, H., Samoliuk, N. \& Ostasz, G. (2019). Effectiveness of Social Dialogue in the System of Sustainable Economic Development Factors. Paper presented at the Proceedings of the 34th International Business Information Management Association Conference, IBIMA 2020: Vision 2025: Education Excellence and Management of Innovations through Sustainable Economic Competitive Advantage, 13303-13313.

Bitkowska, A. (2019). From classical to integrated process management in organizations. Warsaw: C.H. Beck Press.

Bulenda, T., Musidłowski, R. (Ed.) (2003). The penitentiary and post-penitentiary system in Poland. Warsaw: Institute of Public Affairs.

Central Management Board of the Prison Service. Quarterly Statistical Information for the fourth quarter during the period of 20012020. Retrieved March 1, 2021, from https://www.sw.gov.pl/strona/Statystyka-kwartalna

Crawley, E., Sparks, R. (2005). Hidden Injuries? Researching the experiences of older men in English prisons. Howard Journal of Criminal Justice, 44(4), 345-356.

Deka, R. (2017), Social readaptation of convicts as one of the conditions for the safety of local communities. In P. Frąckowiak, M. Szykut (Ed.), Multiple dimensions of prevention, social rehabilitation and social readaptation. Tradition, modernity and prospects of probation initiatives. Toruń: Educational Publishing House “AKAPIT” (pp. 135-148).

Felczak, J. (2020). Impact of the personal situation of convicts on their social rehabilitation and social readaptation, Social Policy, 9, $18-24$.

Fidelus, A.H. (2012). Determinants of social readaptation of convicts. Warsaw: Publishing house of the Cardinal Stefan Wyszyński University.

Fidelus, A.H. (2017). Working with convicts from the perspective of the social and spatial model. Pedagogical Forum, 1, 37-48. http:// cejsh.icm.edu.pl/cejsh/element/bwmeta1.element.ojs-doi-1021697fp2017104 or Retrieved 1 March, 2021 from URL 
Galanter, M., Glickman, L., Dermatis, H., Tracy, K., McMahon, C. (2009). The importance of the patient's spirituality in the treatment process. Postgraduate Psychiatry, 6(1), 28-35.

Gawrycki, F.W., Krupecka, M. (Ed.) (2012). Problems of social policy. Selected theoretical and practical issues. Poznań: Polish Society for Social Policy.

Giddens, A. (2003). The constitution of society. An outline of the theory of structuration. Poznan: Zysk i S-ka Publishing House.

Grzesiak, S. (2017). Inclusion of the excluded in culture - methodical contexts of socialization and cultural activities of penitentiary educators. In A. Haratyk, N. Zayachkivska (Ed.), The development of Polish and Ukrainian pedagogical theory and practice in the nineteenth and twenty-first centuries. vol. 7, Wroclaw: ATUT Publishing House.

Grzesiak, S. (2019). Halfway houses in The Polish Model of Social Reintegration - possibilities and limitations. The Prison Systems Review, 105, 33-56.

Grzesiak, S. (2019a). Prevention of criminal recidivism as a change management process in conditions of prison isolation. In L. Kołtun, T. Kośmider (Ed.), Contemporary dimension of public safety. Shaping safe spaces. Preventive measures. Warsaw: Publishing house of the Institute of Justice.

Grzesiak, S., Mituła-Grzesiak, E. (2020). Reading penitentiary space from prison letters. In S. Grzesiak (Ed.), Psychopedagogical contexts of imprisonment penalty. Warsaw: DiG Publishing House, Publishing House of the Higher School of Criminology and Penitentiary Science in Warsaw.

Institute of Civil Affairs. Retrieved March 1, 2021, from https://instytutsprawobywatelskich.pl/

Iwanowska, A. (2013). Preparation of convicts for life in freedom pursuant to Art. 164 of the Executive Penal Code, Warsaw: Office of the Ombudsman.

Jaworska, A. (2012). Personal and social resources of convicts in the process of penitentiary interventions. Cracow: Impulse Publishing House.

Kieszkowska, A. (2012). Inclusive-catallactic model of social reintegration of convicts. Cracow: Impulse Publishing House.

Kieszkowska, A. (2019). Possibilities of working with socially excluded people in the inclusive-catallactic model in the process of social re-integration. Pedagogical Annals, 11(47)/2019. http://dx.doi.org/10.18290/rped.2019.11s-15 or Retrieved 4 March, 2021 from URL

Kojder, A. (2001). The Pathology of Institutions. In W. Kuczyński (Ed.), The 10th Anniversary of Independent Poland 1989-1999, Warsaw: Publisher: United Publishers \& Productions.

Konopczyński, M. (2013). Reflections on the Polish rehabilitation reality. The crisis of rehabilitation or the success of apparent actions. Warsaw: PEDAGOGIUM Publishing House.

Kosonoga-Zygmunt, J. (2016). Legal recidivism in selected Member States of the European Union. Warsaw: Publishing house of the Institute of Justice.

Lewicka-Zelent, A., Stasiorowski, S. (2020). Financial mechanisms supporting the social rehabilitation of the prison service towards prisoners. Annales Universitatis Mariae Curie-Skłodowska. Sectio J, Paedagogia-Psychologia, 33(4), 49-67. https://doi. org/10.17951/j.2020.33.4.49-67 or Retrieved 2 March, 2021 from URL

Machel, H. (2008). The sense and nonsense of penitentiary social rehabilitation - the case of Poland. Cracow: Impulse Publishing House.

Marzec-Holka, K., Mirosław-Nawrocka, K., Moleda, J. (Ed.) (2014). Contemporary conditions and patterns of social rehabilitation, reintegration and inclusion processes. Warsaw: Publishing house of the Academy of Special Education.

Mastalski, J. (2006). Axiological dimensions of the fight against stress. The Art of Treatment, vol.13, 1-2, 59-66.

Ministry of Justice. Victims'Assistance Fund and Post-penitentiary Assistance - Justice Fund. Retrieved March 1, 2021, from https:// www.funduszsprawiedliwosci.gov.pl/pl/konkursy/pomoc-postpenitencjarna/

Ministry of Justice. Fund of Justice. Retrieved March 1, 2021, from https://www.funduszsprawiedliwosci.gov.pl/pl/znajdz-osrodekpomocy/

Ministry of Justice. Return to crime in 2009-2015. Retrieved March 1, 2021, from https://www.isws.ms.gov.pl > baza-statystyczna > publikacje > download,3502,1 
Morel, J., Palier, B., Palme, J. (2015). Social policy as an investment. Warsaw: Publishing House Janusz Korczak Pedagogical University in Warsaw a 2015.

Muskała, M. (2016). "Desistance from crime” in the theory and practice of rehabilitation. Poznan: Adam Mickiewicz University Scientific Publishers.

Muskała, M. (2017). Social readaptation in the light of the concept of desistance from crime. In A. Barczykowska, M. Muskała (Ed.), Jubilee Book of Professor Wiestaw Ambrozik. Poznań: Adam Mickiewicz University Scientific Publishers, 445-444.

Supreme Audit Office (2018). Social assistance provided to people leaving prisons. Warsaw. Retrieved March 3, 2021, from https:// www.nik.gov.pl/plik/id,21532,vp,24180.pdf

Supreme Audit Office (2015). Social readaptation of people sentenced to several years of imprisonment. Warsaw. Retrieved March 1, 2021, from https://www.nik.gov.pl/kontrole/P/14/044/

Mishchuk, H., Roshchyk, I. Sułkowska, J. \&Vojtovič, S. (2019). Prospects of Assessing the Impact of External Student Migration on Restoring the Country's Intellectual Potential (Case Study of Ukraine). Economics \& Sociology, 12(3), 209-219. DOI: 10.14254/2071789X.2019/12-3/14

Nowak, B.M. (2012). Family in crisis. Rehabilitation study. Warsaw: Polish Scientific Publishers PWN.

Nowak, B.M. (2014). Creating social measures of resocialising and readaptative character. Network and system approach. Polish Journal of Social Rehabilitation, 7, 29-44.

Nowak, B.M. (2015). Social reintegration of prisoners in selected European Union countries. Polish Journal of Social Rehabilitation, $10,55-79$.

Nowak, B.M. (2016). Interdisciplinary, network-system approach to the process of social readaptation and reintegration of convicted people and their families. Educational Studies, 41, 233-249.

Nowak, B.M. (2020). (Not)doomed to exclusion. From pathology to the norm of social behaviour. Warsaw: DiG Publishing House, Publishing House of the Higher School of Criminology and Penitentiary Science in Warsaw.

Piątek, K., Kośmicki, E., Kusztelak, A., Stępień, J. (Ed.) (2016). The social dimension of regional policy. Poznan: Publishing House of the Polish Society for Social Policy.

Pilch, T. (2001). Principles of pedagogical research: quantitative and qualitative strategies. Warsaw: Academic Publishing House ŻAK.

Pindel, E. (2019). The process of the social readaptation of crime perpatrators. From a penitentiary facility to freedom. Cracow: Impulse Publishing House.

Pospiszyl, K. (2020). Risk-need-responsivity. A multifaceted diagnostic and rehabilitation model. The Prison Systems Review, 109, $5-22$.

Pytka, L. (2005). Rehabilitation education. Selected theoretical, diagnostic and methodological issues. Warsaw: Publishing house of the Academy of Special Education.

Regulation of the Prime Minister of 28 December 2016 on the cooperation of entities in the implementation of penalties, punitive, compensatory, protective, preventive measures and forfeit, as well as social control over their implementation (Journal of Laws of 2016, item 2305.)

Second Chance Act of 2007. Retrieved March 5, 2021, from https:/www.govinfo.gov/content/pkg/PLAW-110publ199/pdf/PLAW110publ199.pdf

Stańdo-Kawecka, B. (2010). Critically on the concept of social rehabilitation in Polish academic texts. Probation, 1, 108-124.

Stasiorowski, S. (2016), Project: Reform of the system of social readaptation of convicts in Poland. Social reintegration of convicts as the most important goal of penalty. Warsaw.

Stasiorowski, S. (2017). System of the social readaptation of convicts], Minutes from the second session of the Kujawsko-Pomorskie Local Council for Social Readaptation and Aid for Convicts, which took place on May 12, 2017 at the Kujawsko-Pomorskie Provincial Office in Bydgoszcz. Retrieved March 3, 2021, from https://www.wloclawek.so.gov.pl/container/Pliki/dokumenty/1496311804.pdf

Stasiorowski, S. (2019). Basic factors influencing the functioning of the system of the social readaptation of convicts - diagnosis and development. Pedagogical Annals, 11(47), 11-23. https://doi.org/10.18290/rped.2019.11s-26 or Retrieved 1 March, 2021 from URL 
Stępniak, P. (2017). (Un)imaginary rehabilitation. On the appropriation of penitentiary space. Warsaw: Difin publisher.

Świerczyńska, K., Kliber, A. (2018). African Emigration to Europe. Social Cohesion and Inequality Nexus. Economics and Sociology, 11(1), 188-204. doi:10.14254/2071-789X.2018/11-1/12

The POMOST Foundation from Zabrze. Retrieved March 1, 2021, from https://www.fundacja-pomost.pl/strona-glowna

PEOPLE FOR PEOPLE Association from Wrocław. Retrieved March 4, 2021, from, http://ludzieludziom.pl/

PATRONAT Penitentiary Association. Retrieved March 4, 2021, from http://www.patronat.eu/

Szczepaniak, P. (2014). Inspirations of social inclusion for social rehabilitation and penitentiary. Social and Rehabilitation Prevention, 24, 143-169.

Szczepanik, R. (2015). Becoming a habitual offender. Institutional careers of people returning to crime. Lodz: Publishing House of the University of Lodz.

Szczygieł, G. (2002). Social readaptation of convicts in the Polish penitentiary system. Bialystok: Temida Publishing House.

Sztuka, J. (2018). The perspective on effectiveness in rehabilitation. Studia Paedagogica Ignatiana, vol. 21, 1, 85-105.

Sztuka, M. (2013). Anachronism and topicality. The idea of rehabilitation in the dispute over modernity. Krakow: Publishing House of the Jagiellonian University.

Sztuka, M. (2007). Effectiveness of interactions in the corrective-oriented model of penal institution. American experiences. Journal of Criminal Law and Penal Sciences, 1, 313-326.

Szymanowski, T. (2005). Penal and penitentiary policies in Poland during the period of changes in criminal law. Warsaw: Publishing House of the University of Warsaw.

Szymanowski, T. (2010). Recidivism in Poland. Problems of criminal law, criminology and criminal policies. Warsaw: Wolters Kluwer publishing house.

Zygmunt, J. (2008). Legal models of eradicating return to crime in Polish criminal law. Journal of Criminal Law and Penal Sciences, $2,223-241$

Slawomir GRZESIAK is the doctor of social sciences in the field of pedagogy, officer of the Prison Service. Pedagogue and administrativist, serving as an assistant professor at the Psychopedagogical Research Laboratory of the Research and Development Institute at the Higher School of Criminology and Penitentiary Science in Warsaw. Research interests: rehabilitation and penitentiary pedagogy; social readaptation of convicts; organizational structure and functioning of the prison system in Poland; prison demographics.

ORCID ID: orcid.org/0000-0001-7701-9402 